\title{
Priority ratings for conservation of Indian primates
}

\section{Anwaruddin Choudhury}

Many of India's primates are threatened, especially by forest destruction, and in some areas they are also hunted for food. The $\mathbf{1 5}$ species involved are not threatened equally-some are widespread and common, even in the hearts of cities, while others survive only in small populations over a limited area. In order to make best use of the limited resources available for primate conservation it is necessary to identify those species needing urgent attention. The author, who is at present carrying out research on the primates of Assam, has rated the species according to their conservation needs using a method based on one developed for identifying conservation priorities for African primates. He compares his results with those of the Asian Action Plan for Primates and makes recommendations for conservation action in India.

India has 15 primates in addition to man (Table 1) and their role in the country's diverse ecosystems, especially tropical forests, is of great importance. Among them is the hoolock gibbon, one of man's closest relatives. Although primates are distributed all over India their associations are particularly rich in north-eastern and southern parts of the country. North-eastern India contains 10 of the 15 species; southern India has five species, while over most of northern India the rhesus monkey and the Hanuman langur are the only primates.

Indian primates are forest-dwellers, except for the Hanuman langur, bonnet and rhesus monkeys, which are common in the heart of the cities and towns, especially around temples and railway stations. The survival of the other species depends on the continued existence of their forest habitats.

With a growing human population (Table 2) India's forest is dwindling fast. Expansion of agriculture, the slash-and-burn shifting cultivation of the hill tribes, illegal tree-felling, dam building and road construction are the main agents responsible. As an illustration of forest destruction, the situation in north-eastern India may be conConservation of Indian primates sidered. This area has lost about 5.5 per cent of its forest cover in a decade (Table 3 ). In addition, in many areas, for example in the hills of northeastern India, primates are killed by tribal people for meat.

Table 1. Classification of Indian primates

\begin{tabular}{ll}
\hline Scientific name & English name \\
\hline $\begin{array}{c}\text { Family Lorisidae } \\
\text { Loris tardigradus } \\
\text { Nycticebus coucang }\end{array}$ & Slender loris \\
Family Cercopithecidae & Slow loris \\
Subfamily Cercopithecinae & \\
Macaca arctoides & Stump-tailed macaque \\
Macaca assamensis & Assamese macaque \\
Macaca fascicularis & Long-tailed or \\
& crab-eating macaque \\
Macaca mulatta & Rhesus monkey \\
Macaca nemestrina & Pig-tailed macaque \\
Macaca radiata & Bonnet macaque \\
Macaca silenus & Lion-tailed macaque \\
Subfamily Colobinae & Hanuman or common langur \\
Presbytis entellus & Golden langur \\
Presbytis geei & Nilgiri langur \\
Presbytis johnil & Phayre's leaf monkey \\
Presbytis phayrei & Capped langur \\
Presbytis pileatus & \\
Family Hylobatidae & Hoolock or \\
Hylobates hoolock & white-browed gibbon \\
\hline
\end{tabular}


Table 2. Growth of human population of India with density since 1901

\begin{tabular}{lll}
\hline Year & $\begin{array}{l}\text { Population } \\
\text { (millions) }\end{array}$ & $\begin{array}{l}\text { Density } \\
\text { per sq km }\end{array}$ \\
\hline 1901 & 238.34 & 77 \\
1911 & 252.00 & 82 \\
1921 & 251.24 & 81 \\
1931 & 278.87 & 90 \\
1941 & 318.54 & 103 \\
1951 & 360.95 & 117 \\
1961 & 439.07 & 142 \\
1971 & 547.95 & $177^{*}$ \\
1981 & 685.18 & 216 \\
\hline
\end{tabular}

Source. Census of India 1981.

* Excluding Jammu and Kashmir, whose figures were not available.

\section{Priority rating}

The status of the 15 species of primates varies and the resources available for conservation are limited. Therefore, priority rating for conservation action has become essential to identify those primates that are most endangered. The priority rating here is based on the Action Plan for African Primate Conservation, 1986-1990 (Oates, 1985).

The species have been rated on the following three parameters: degree of threat, taxonomic uniqueness of species, and association of species with other threatened forms. The criteria for rating are as follows.

Table 3. Area under forest in North Eastern States of India during 1972-1975 and 1980-1982 based on visual interpretation of Landsat data

\begin{tabular}{|c|c|c|c|c|c|}
\hline \multirow[b]{2}{*}{ States } & \multirow[b]{2}{*}{ Period } & \multicolumn{2}{|l|}{ Area (sq km) } & \multirow{2}{*}{$\begin{array}{l}\% \text { of } \\
\text { total forest } \\
\text { area }\end{array}$} & \multirow{2}{*}{$\begin{array}{l}\% \text { of closed } \\
\text { forest to total } \\
\text { geographical area }\end{array}$} \\
\hline & & $\begin{array}{l}\text { Total geographical } \\
\text { area }\end{array}$ & $\begin{array}{l}\text { Total forest } \\
\text { area }\end{array}$ & & \\
\hline Arunachal Pradesh & $1980-1982$ & 83580 & 52104 & 62.3 & 59.2 \\
\hline \multirow{2}{*}{ Assam } & $1972-1975$ & \multirow{2}{*}{78520} & 21055 & 26.8 & 23.8 \\
\hline & $1980-1982$ & & 19796 & 25.2 & 19.9 \\
\hline \multirow{2}{*}{ Manipur } & $1972-1975$ & \multirow{2}{*}{22360} & 15090 & 67.5 & 61.2 \\
\hline & $1980-1982$ & & 13572 & 60.7 & 50.5 \\
\hline \multirow{2}{*}{ Meghalaya } & $1972-1975$ & \multirow{2}{*}{22490} & 14390 & 64.0 & 44.8 \\
\hline & $1980-198 \mathrm{~N}$ & & 12458 & 55.4 & 33.1 \\
\hline \multirow{2}{*}{ Mizoram } & $1972-1975$ & \multirow{2}{*}{21090} & 13860 & 65.7 & 62.6 \\
\hline & $1980-1982$ & & 11971 & 56.8 & 52.9 \\
\hline \multirow{2}{*}{ Nagaland } & $1972-1975$ & \multirow{2}{*}{16530} & 8154 & 49.3 & 42.8 \\
\hline & $1980-1982$ & & 8095 & 49.0 & 29.8 \\
\hline \multirow{2}{*}{ Tripura } & $1972-1975$ & \multirow{2}{*}{10480} & 6330 & 60.4 & 57.0 \\
\hline & $1980-1982$ & & 5138 & 49.0 & 43.4 \\
\hline \multirow[b]{3}{*}{ Total } & $1972-1975$ & & 13860 & 65.7 & 62.6 \\
\hline & $1972-1975$ & \multirow{2}{*}{255050} & 130317 & 51.1 & 46.7 \\
\hline & $1980-1982$ & & 123134 & 48.3 & 40.0 \\
\hline
\end{tabular}

Source: National Remote Sensing Agency (NRSA). 
Degree of threat

(1) Not known to be especially rare or threatened.

(2) Rare or at risk. Populations exist at a low density and /or in a limited geographical area, and individuals may not be readily located in a shortterm search even by professionals; or, a widely distributed species not yet under threat as a whole, but with a significant number of populations definitely at risk from habitat alteration and/or hunting.

(3) Vulnerable. Populations have limited distribution and/or ecological tolerance, and current rates of habitat alteration and/or hunting pressure are likely to intensify; or, current rate of habitat alteration and/or hunting are slowly but significantly diminishing most populations. High probability of moving to category 4 by the year 2000 if no new conservation measures are taken.

(4) Highly vulnerable. Surviving populations are small or fragmented, and threatened by habitat destruction and/or hunting. Likely to move to category 5 by year 2000 if no new conservation measures are taken.

(5) Endangered. Population restricted to a very limited area, or with a very fragmented distribution; fewer than 25,000 individuals probably remain, and these are threatened by major habitat alteration and/or severe hunting; likely to move to category 6 by the end of the century if current destructive forces continue to operate.

(6) Highly endangered. Fewer than 10,000 individuals remain, and no large section of the population is really secure.

Taxonomic uniqueness

(1) A member of a large species group (i.e. one of several closely related species), or species status sometimes questioned, but at least a distinct subspecies.

(2) A very distinct species, or one of a small number of closely related forms, which together are clearly distinct from other species.

(3) The only member of a monotypic genus (or family), or member of a genus with only two species.

Association with other threatened primates

(1) A wide-ranging species, and/or most of range does not overlap with any highly threatened form.

(2) A major part of the species's range overlaps with one or more highly threatened forms, or several that are under moderate threat.

The results of the rating of Indian primates are listed in Table 4, which also gives the results of the ratings given in the Asian Action Plan (Endey, in press).

Table 4. Priority ratings for conservation of Indian primate species

\begin{tabular}{|c|c|c|c|c|c|c|c|c|}
\hline \multirow[b]{2}{*}{ Species } & \multicolumn{4}{|c|}{ Scores using system based on Oates (1985) } & \multicolumn{4}{|c|}{$\begin{array}{l}\text { Scores published in Asian Action Plan for Primates } \\
\text { (Endey, in press) }\end{array}$} \\
\hline & $\begin{array}{l}\text { Degree of } \\
\text { threat }\end{array}$ & $\begin{array}{r}\text { Taxonomic } \\
\text { uniqueness }\end{array}$ & $\begin{array}{l}\text { Association } \\
\text { with other } \\
\text { threatened } \\
\text { forms }\end{array}$ & $\begin{array}{l}\text { Total } \\
\text { rating }\end{array}$ & $\begin{array}{l}\text { Degree of } \\
\text { threat }\end{array}$ & $\begin{array}{l}\text { Taxonomic } \\
\text { uniqueness }\end{array}$ & $\begin{array}{l}\text { Association } \\
\text { with other } \\
\text { threatened } \\
\text { forms }\end{array}$ & $\begin{array}{l}\text { Total } \\
\text { rating }\end{array}$ \\
\hline Loris tardigradus & 1 & 3 & 1 & 5 & 3 & 3 & 1 & 7 \\
\hline Nycticebus coucang & 1 & 3 & 2 & 6 & 1 & 2 & 1 & 4 \\
\hline Macaca arctoides & 4 & 2 & 2 & 8 & 4 & 2 & 1 & 7 \\
\hline Macaca assamensis & 3 & 2 & 1 & 6 & 3 & 1 & 1 & 5 \\
\hline Macaca fascicularis & 6 & 2 & 1 & 9 & 2 & 1 & 1 & 4 \\
\hline Macaca mulatta & 1 & 1 & 1 & 3 & 2 & 1 & 1 & 4 \\
\hline Macaca nemestrina & 3 & 2 & 2 & 7 & 3 & 1 & 1 & 5 \\
\hline Macaca radiata & 1 & 1 & 1 & 3 & 2 & 1 & 1 & 4 \\
\hline Macaca silenus & 5 & 2 & 2 & 9 & 6 & 1 & 2 & 9 \\
\hline Presbytis entellus & 1 & 1 & 1 & 3 & 2 & 2 & 1 & 5 \\
\hline Presbytis geei & 6 & 2 & 1 & 9 & 3 & 1 & 1 & 5 \\
\hline Prebytis johnii & 5 & 2 & 2 & 9 & 5 & 2 & 2 & 9 \\
\hline Presbytis phayrei & 6 & 2 & 2 & 10 & 3 & 1 & 1 & 5 \\
\hline Presbytis pileatus & 1 & 2 & 2 & 5 & 3 & 1 & 1 & 5 \\
\hline Hylobates hoolock & 5 & 2 & $\overline{2}$ & 9 & 5 & 2 & 1 & 8 \\
\hline
\end{tabular}




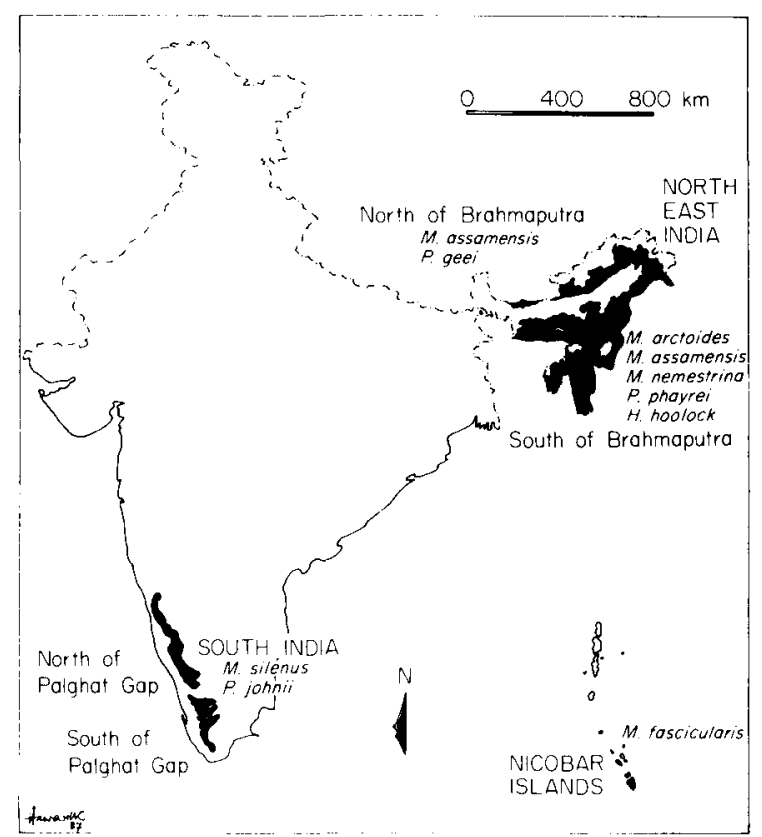

Map of India showing three regions and four sub-regions of endangered primate concentration. Regions are mapped on the basis of approximate distribution of primates and the existing forest cover.

\section{Discussion}

This rating system's main intention is to give highly endangered species conservation priority. According to the system the most endangered species can accrue maximum overall scores of 11 . But, despite the best efforts to give objective ratings, some anomalies remain. For example, in 'taxonomic uniqueness' Presbytis geei will be given the rating of 2 , while Nycticebus coucang receives the rating of 3 . The former is more endangered, however, and needs more attention.

From Table 4 it appears that 9 species (60 per cent of Indian primate species) need some conservation attention, having a score greater than 1 for 'degree of threat'. The species with ratings of 9 and 10 need priority: Presbytis phayrei, with a total rating of 10 , is closely followed by Macaca fascicularis, $M$. silenus, $P$. geei. $P$. johnii and Hylobates hoolock, all with total ratings of 9 . These six species need the highest conservation priority at present in India. Macaca arctoides has a 92 total rating of $8, M$. nemestrina one of 7 and $M$. assamensis is also regarded as vulnerable, with a threat rating of 3 .

If one compares my rating results with those given in the Asian Action Plan (Endey, in press) some discrepancies are apparent (Table 4).

Loris tardigradus. I assigned a score of 1 for the 'degree of threat' (against 3 of the Asian Action Plan) due to the fact that it is not known whether this species is rare or threatened. No proper survey has been carried out and since the species is mostly nocturnal, sightings are very rare. However, its range is believed to be quite large, extending as far north as the Tapti river, north of Bombay (Roonwal and Mohnot, 1977).

Nycticebus coucang. In the Indian context the 'taxonomic uniqueness' of this species undoubtedly deserves a score of 3 . Regarding 'association with other threatened primates', within India its range overlaps with many threatened species- $M$. arctoides, $M$. assamensis, $M$. nemestrina, $P$. phayres and $H$. hoolock-hence I assigned it a score of 2 .

Macaca arctoides. The only discrepancy is in 'association with other threatened primates', and I assigned it a score of 2 because its range in India mostly overlaps with $M$. assamensis, $M$. nemestrina, $P$. phayrei and $H$. hoolock, all of which are threatened.

Macaca assamensis. There is no doubt that this is a distinct species and deserves a score of 2 in 'taxonomic uniqueness'.

Macaca fascicularis. This species is a common primate of South-East Asia, but I assigned a score of 6 for 'degree of threat' because within India it is restricted to three tiny islands in the Bay of Bengal, and is recognized as an endemic subspecies, M. f. umbrosa (Roonwal and Mohnot, 1977). I assigned a score of 2 for taxonomic uniqueness because it is a distinct sub-species.

Macaca mulatta. This species is neither rare nor at risk; individuals can still be located readily in India, even by amateurs, and therefore I assigned a score of 1 for 'degree of threat'.

Oryx Vol 22 No 2, April 1988 
Macaca nemestrina. I assigned a score of 2 both for 'taxonomic uniqueness' and 'association with other threatened primates' because it is a distinct species, most of whose range overlaps with many endangered forms $-M$. arctoides, $P$. phayrei and H. hoolock.

Macaca radiata. Like $M$. mulatta, this species is neither rare nor at risk, so scores only 1 for 'degree of threat'.

Macaca silenus. It was believed that this species occurred only in the forested areas of Tamil Nadu and Kerala (Roonwal and Mohnot, 1977), and Krishnan (1972) referred to Kerala as its main last stronghold. However, Karanth (1985) estimated a population of about 3000 in Karnakata. Reliable estimates are not available for Tamil Nadu and Kerala, but it is believed that the populations there are higher than was previously thought. Moreover, many sanctuaries and reserves, notably Kalakkad, Mundanthurai and Silent Valley, protect large sections of the populations and hence I assigned it a score of 5 for 'degree of threat'.

Presbytis entellus. Like $M$. mulatta and $M$. radiata, this species is not rare.

Presbytis geei. This species is highly endangered in India, with a very limited distribution and a population nowhere near 10,000. The rough estimate by the Forest Department puts the figure for Assam at about 500; Mukherjee (1980) counted 305 individuals in the same area. There is no estimate for the population in Bhutan, but it may be slightly higher than that of Assam. I believe that even at Asian level it should be assigned a score of 6 for 'degree of threat'.

Presbytis phayrei. Although this species is widely distributed in other Asian countries, for example in Burma and Thailand, its distribution in India is very limited. The population estimate for Tripura is about 500 (Mukherjee, 1982). In southern Assam my own estimate based on field work is 'less than Tripura' as there is less available habitat. So far not a single troop, let alone any large section, is really secure due to slash-andburn agriculture, encroachment, poaching by tribal people and lack of sanctuaries. Regarding 'association with other threatened primates' it deserves a score of 2 because almost its entire Conservation of Indian primates range in India overlaps with those of $M$. arctoides, $M$. nemestrina and $H$. hoolock.

Presbytis pileatus. I assigned a score of 1 for 'degree of threat' since this species is still common in forested areas of north-eastern India. However, it may approach a score of 2 or 3 by another decade due to habitat destruction and hunting, especially in hill areas dominated by certain tribal people: the Nagas, Kukis and Mizos. Regarding 'association with other threatened primates' it deserves a score of 2 because a major part of its range overlaps with those of $M$. arctoides, $M$. assamensis, $M$. nemestrina, $P$. phayrei and $H$. hoolock.

Hylobates hoolock. The only discrepancy is in 'association with other threatened primates' and I assigned a score of 2 since the major part of its range overlaps with those of $M$. arctoides, $M$. assamensis, $M$. nemestrina and $P$. phayrei.

It is inevitable that there should be discrepancies when comparing ratings for species in India and in Asia, since some species, for example $P$. phayrei and $M$. fascicularis, have wide distributions in South-East Asia, but limited ones in India.

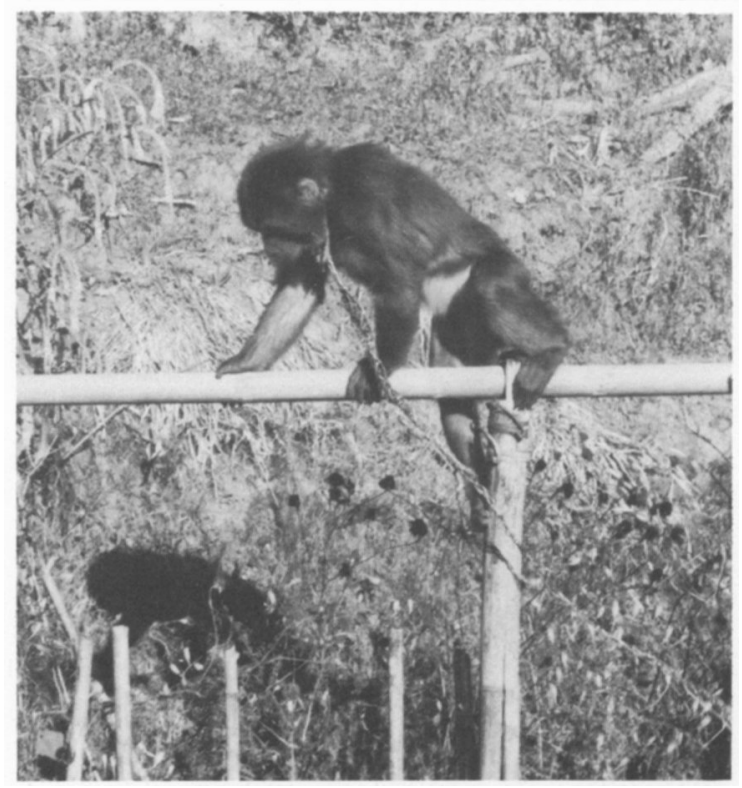

Captive stump-tailed macaque in a tribal village in the North Cachar Hills, Assam. Very little is known about the exact distributions of this species. Also restricted to the forests south of the Brahmaputra River (A. Choudhury). 


\section{Recommendations}

The Government of India should take immediate measures to protect the habitats of the highly endangered species. These measures should include the establishment of new reserves and effective management of existing reserves. In some cases existing reserves may need extending. A large reserve, of about $1800 \mathrm{sq} \mathrm{km}$, in southern Assam (Cachar), for which a proposal was made to the Government of Assam in 1983 (as Dhaleswari wildlife sanctuary/national park), would provide the only safe refuge for $P$. phayrei in India, and also contains good populations of $H$. hoolock, $P$. pileatus, $M$. mulatta and $N$. coucang. The area may also contain $M$. arctoides, $M$. assamensis and $M$. nemestrina. The contiguous forested areas of neighbouring Manipur, Mizoram and Tripura should also be included and be made into a Biosphere Reserve under the Man and Biosphere programme.

Four small reserves, as there is little possibility of bigger ones in those areas, are recommended in the Barail region of Assam and in the Great Nicobar, Little Nicobar and Katchall islands of Andamans. The Barail reserve, about $150 \mathrm{sq} \mathrm{km}$ covering the Barail Reserve Forest and the areas near Jatinga, a village made famous by its annual bird-killing, would be ideal for taking an initiative in the area for primate conservation. Besides $N$. coucang, $M$. arctoides, $M$. mulatta, $P$. pileatus and $H$. hoolock, $M$. assamensis and $M$. nemestrina may also exist there.

The Nicobar Islands in the Bay of Bengal are the only home of $M$. fascicularis umbrosa. Since this is a distinct local population with a very limited geographical distribution, special attention is required for its preservation if the existing diversity of Indian primates is to be maintained. A $100-\mathrm{sq}-\mathrm{km}$ reserve in Great Nicobar Island stretching from the sea to the hills, and a 10-15sq-km reserve in both Little Nicobar and Katchall islands are recommended.

Extension of the core area of Manas reserve for securing the future of $P$. geei, and more effective management of Kalakkad, Mundanthurai and Silent Valley reserves for $M$. silenus and $P$. johnii, are also recommended. Control of the hunting of primates for food in primate-rich north-eastern India is also necessary if a complete ban is impossible.

\section{References}

Endey, A.A. (compiler) (in press). Action Plan for Asian Primate Conservation: 1986-1990. IUCN/SSC Primate Specialist Group, New York.

Karanth, K.U. 1985. Ecological status of lion-tailed macaque in Karnataka, India. Primate Conservation, 6, 73-84.

Kirshnan, M. 1972. An ecological survey of the larger mammals of peninsular India. Part 1. J. Bombay Nat. Hist. Soc. 68, 503-555.

Mukherkjee, R.P. 1980. Distribution and present status of the golden langur in some forests of Assam, India. Proc. Wildlife Workshop, Zool. Surv. of India, 129-132.

Mukherjee, R.R. 1982. Phayre's leaf monkey of Tripura. J. Bombay Nat. Hist. Soc. 79, 47-56.

Oates, J.F. (compiler) 1985. Action Plan for African Primate Conservation: 1986-1990. IUCN/SSC Primate Specialist Group. New York.

Roonwal, M.L. and Mohnot, S.M. 1977. Primates of South Asia: Ecology, Sociobiology and Behavior. Harvard University Press, Cambridge, Mass.

Anwaruddin Choudhury, c/oMs S.B. Choudhury, Translator, Gauhati High Court, Guwahati 781001 Assam, India. 